\title{
Pengaruh Penerapan E-Filing terhadap Kepatuhan Pelaporan Wajib Pajak dengan Pemanfaatan Media Sosial sebagai Variabel Moderasi
}

Akuntansi

\author{
Celintara Anindya Ayu Wardhani ${ }^{1 *}$, Sarah Kristina ${ }^{2}$, dan Priyo Hari Adi ${ }^{3}$ \\ ${ }^{1,2,3}$ Fakultas Ekonomika dan Bisnis, Universitas Kristen Satya Wacana \\ E-mail: celintaraanindya@gmail.com
}

\begin{abstract}
This study aims to analyze the effect of applying e-filing to taxpayer reporting compliance with the use of social media as a moderating variable. The data used are primary data in the form of questionnaires taken directly through filling out questionnaires distributed via online media using Google Form. The sampling method in this study uses a purposive sampling method with taxpayer criteria using social media. The results showed that the application of e-filing had a significant positive effect on compliance with taxpayer reporting while the use of social media was not able to moderate the effect of e-filing on taxpayer reporting compliance.
\end{abstract}

Keywords: E-Filing, taxpayer reporting compliance, social media

\section{PENDAHULUAN}

Teknologi yang semakin maju sangat berpengaruh dalam bidang perpajakan. Hal ini, membuat Direktorat Jenderal Pajak (DJP) menghadirkan inovasi baru yaitu dengan mengeluarkan ketentuan mengenai penyampaian Surat Pemberitahuan Elektronik (E-SPT) yang telah diatur dalam Peraturan Direktur Jenderal Pajak Nomor PER-03/PJ/2015 tentang Penyampaian Surat Pemberitahuan Elektronik yang dapat mempermudah WP sehingga tidak perlu datang ke Kantor Pelayanan Pajak (KPP) dan juga lebih efisien waktu dan biaya. Menurut Sukmana (2019), DJP menyebutkan 11,3 juta WP sudah melaporkan SPT hingga 1 April 2019, termasuk 278.000 WP Badan. Jumlah tersebut meningkat $6,6 \%$ dibandingkan periode lalu yang berkisar 10,6 juta. Secara keseluruhan, WP yang melaporkan SPT hanya $61,7 \%$.

Adanya peraturan tersebut membuat DJP menghadirkan E-filing dan $E$ form. E-filing dan E-form merupakan media pelaporan yang membutuhkan jaringan internet dan perangkat untuk memasukkan laporan tahunan Wajib Pajak (WP), hanya 
saja $E$-filing dan E-form memiliki perbedaan yaitu E-filing harus mendapat akses internet dari awal hingga berakhirnya proses pelaporan menggunakan E-filing, sedangkan E-form membutuhkan akses internet ketika mengunduh dan mengunggah file SPT, hanya saja E-form baru dapat digunakan oleh WP pengusaha dan karyawan dengan penghasilan diatas Rp 60 juta. Menurut Nurhayati \& Hidayat (2019), WP lebih memilih menggunakan E-filing dalam menyampaikan SPT dimasa yang akan datang dibandingkan menggunakan E-form.

DJP Kementerian Keuangan menerbitkan Peraturan Dirjen Pajak Nomor PER-02/PJ/2019 tentang Tata Cara Penyampaian, Penerimaan, dan Pengolahan Surat Pemberitahuan. Kebijakan ini merupakan penerapan dari Peraturan Menteri Keuangan Nomor 9/PMK.03/2018, dan mengubah tujuh kebijakan DJP sebelumnya perihal penyampaian Surat Pemberitahuan (SPT). Berdasarkan kebijakan yang telah diubah dalam PER-02/PJ/2019 yaitu WP diwajibkan untuk menyampaikan SPT melalui E-Filing guna meringankan beban administrasi WP, sehingga dapat meningkatkan kemudahan usaha WP. Apabila WP yang menyampaikan SPT selain menggunakan E-Filing seperti penyampaian secara langsung atau via pos, maka SPT yang disampaikan tidak diterima dan akan diberikan kembali kepada WP. Pengisian $e$-filing tidak selalu dilakukan sendiri oleh WP. Jika WP merasa kesulitan dan tidak memahami dalam penggunaan $e$-filing serta sistem komputerisasi, maka WP akan menggunakan jasa pihak ketiga untuk mengisi $e$-filing .

DJP menilai bahwa diperlukannya sosialisasi yang bersifat terobosan atau pemasaran. Penggunaan media sosial menurut DJP merupakan tempat yang efektif untuk memberikan informasi kepada penggunanya yang bisa di akses seluruh masyarakat Indonesia hingga ke penjuru negeri. Media sosial lebih murah dibandingkan dengan media elektronik lainnya. Manfaat yang dimiliki media sosial tidak hanya dampak positif tetapi juga dampak negatif. DJP memanfaatkan sarana media sosial untuk mengedukasi WP dan calon WP mengenai pajak dan segala peraturan yang ada.

DJP mengeluarkan Keputusan Direktur Jenderal Pajak Nomor KEP273/PJ/2013 tentang Pengelolaan Akun Direktorat Jenderal Pajak di Jejaring Media Sosial dan Keputusan Direktur Penyuluhan, Pelayanan dan Hubungan Masyarakat dan KEP-03/PJ.09/2015 tentang Tim Pengelola Akun Resmi Media Sosial Direktorat Jenderal Pajaksebagai dasar penggunaan media sosial resmi Ditjen Pajak yaitu Twitter, Facebook, Youtube 
dan Instagram. Media sosial resmi dimanfaatkan untuk sarana edukasi yang baru untuk mengurangi kesenjangan masyarakat yang selama ini masih dialami masyarakat Indonesia.

Penelitian Aminnudin, Ali, \& Subadriyah (2019), Susmita \& Supadmi (2016), dan Sulistyorini, Nurlaela, \& S. Chomsatu (2017) menemukan bahwa penggunaan sistem e-filing berpengaruh positif terhadap kepatuhan WP. Berbeda dengan penelitian yang dilakukan oleh Handayani \& Tambun (2016), yang menemukan bahwa penelitian tersebut tidak mendukung adanya pengaruh penerapan $e$ filing terhadap kepatuhan WP karena meskipun pengunaan $e$-filing mudah tetapi belum praktis menurut WPOP sehingga kepatuhan dapat mengalami kenaikan atau penurunan.

Penelitian Mahadianto \& Astuti (2017) menemukan bahwa sosialisasi menggunakan media sosial tidak mendukung peningkatan kepatuhan WP karena WP tidak tahu akan adanya sosialisasi pajak. Sedangkan menurut Lado \& Budiantara (2018) menyatakan perlu adanya sosialisasi secara berulang dari DJP mengenai penyampaian SPT melalui e-filing. Dengan adanya pemanfaatan media sosial, Ditjen Pajak menjadi lebih leluasa berinteraksi dengan masyarakat di dunia maya dan diharapkan kesan pajak yang dulu dianggap mengerikan tergantikan dengan pandangan pajak sebagai mitra wajib pajak yang ramah, dan menyenangkan. Diharapkan hal tersebut berimbas terhadap meningkatnya kepatuhan pelaporan pajak oleh wajib pajak yang sadar akan kebutuhan bukan karena terpaksa. Dari penjelasan tersebut peneliti memutuskan untuk melakukan penelitian yang serupa dengan menggunakan variabel moderasi pemanfaatan media sosial dikarenakan variabel tersebut dapat mendukung sosialisasi berbasis online yang dapat dilakukan secara berulang oleh DJP dalam mengedukasi mengenai perpajakan terutama penerapan e-filing dan dinilai efektif dalam memberikan informasi kepada penggunanya yang terbukti dengan dikeluarkannya Keputusan Direktur Jenderal Pajak Nomor KEP-273/PJ/2013.

Penelitian ini bertujuan untuk menganalisis pengaruh penerapan $e$-filing terhadap kepatuhan pelaporan WP dengan pemanfaatan media sosial sebagai variabel moderasi. Manfaat dari penelitian ini diharapkan dapat memberikan pengetahuan yang luas mengenai penggunaan media sosial sebagai sumber informasi tentang kepatuhan pelaporan WP. Perumusan masalah yang terdapat dalam penelitian ini yaitu: 1) Apakah penggunaan $e$-filing berpengaruh terhadap kepatuhan pelaporan WP? 2) Apakah pemanfaatan media sosial 
berpengaruh terhadap kepatuhan pelaporan WP?

\section{TINJAUAN PUSTAKA}

\section{Pemanfaatan Media Sosial}

Kaplan \& Haenlein (2014) mendefinisikan media sosial sebagai sekelompok aplikasi online yang dibangun di atas landasan pemikiran dan teknologi Web yang memungkinkan pembentukan dan perputaran konten yang dibuat oleh pengguna. Sedangkan Vries, Gensler, \& Lee (2012) melakukan penelitian tentang bagaimana media sosial dapat digunakan untuk mengelola komunikasi pemasaran. Putri, Nurwati, \& S (2016) menyebutkan bahwa ada beberapa dampak positif dari media sosial. Dampak-dampak tersebut yaitu untuk tempat promosi yang baik dan murah, dapat memperluas jaringan pertemanan, media komunikasi yang mudah, dan tempat berbagi dan mencari informasi yang bermanfaat.

\section{Direktorat Jenderal Pajak (DJP)} memanfaatkan media sosial sebagai media untuk memberikan edukasi dan sosialisasi tentang hal-hal baru yang terdapat dalam perpajakan. Media sosial dimanfaatkan sebagai tempat penyampaian saran dan kritik dari WP untuk DJP agar dapat memperbaiki pelayanan, dan juga untuk memberikan informasi antar WP mengenai $e$ filing.

\section{Kepatuhan Pelaporan Wajib Pajak}

Norman D. Nowak (2004) yang terdapat dalam penelitian Devano \& Rahayu (2006) mengemukakan kepatuhan WP sebagai suatu kondisi kepatuhan dan kesadaran terhadap pemenuhan kewajiban perpajakan yang tergambar dalam situasi seperti WP berusaha untuk memahami semua peraturan perundang-undangan perpajakan, harus jelas dan lengkap dalam mengisi formulir pajak, akurat dalam menghitung jumlah pajak yang terutang, tepat waktu dalam pembayaran pajak yang terutang.

Kepatuhan pajak menurut Hutasoit (2017) digambarkan sebagai suatu keadaan saat WP melengkapi semua kewajiban perpajakan dan melakukan hak perpajakannya. Kepatuhan pajak diperinci menjadi dua, yaitu kepatuhan pajak formal dan kepatuhan pajak material. Kepatuhan pajak formal merupakan kepatuhan yang disesuaikan dengan ketentuan undang-undang perpajakan, contohnya NPWP bagi yang telah memiliki penghasilan, tidak terlambat dalam melaporkan SPT Masa maupun Tahunan, tidak terlambat dalam melunasi utang pajak. Kepatuhan pajak material merupakan suatu keadaan saat WP memenuhi semua ketentuan material perpajakan yang terdapat dalam undangundang perpajakan. 
Kriteria kepatuhan WP menurut Keputusan Menteri Keuangan No. 544/KMK.04/2000 pasal 1 yaitu tepat waktu dalam menyampaikan SPT, tidak mempunyai tunggakan pajak, tidak pernah dijatuhi hukuman pidana, dan sebagainya. Sedangkan menurut Nasucha (2004), kepatuhan WP diidentifikasikan ke dalam WP patuh dalam mendaftarkan diri, patuh dalam penyetoran kembali SPT, dan patuh dalam penghitungan serta pembayaran tunggakan pajak.

\section{Penerapan E-Filing}

E-filing merupakan cara penyampaian SPT dengan menggunakan internet melalui website DJP. Tidak hanya melalui website DJP, akses resmi untuk pelaporan SPT juga dapat dilakukan di Online Pajak, BRI, SPT, dan Pajakku. WP tidak harus mencetak seluruh formulir laporan serta menunggu untuk mendapatkan tanda terima manual. E-filing ini dibuat agar tidak ada kesalahpahaman antara WP dengan aparat pajak dan WP dapat mengawasi SPT karena mereka yang membuat (Akib \& Amdayani, 2013).

Sistem e-filing memiliki beberapa kelebihan, yaitu penyampaian SPT menjadi lebih cepat karena dapat dilakukan dimana saja dan kapan saja dengan memanfaatkan jaringan internet, situs DJP dapat diakses tanpa dipungut biaya sehing- ga biaya pelaporan SPT menjadi lebih murah, dengan menggunakan sistem komputer dapat membuat penghitungan lebih cepat dan akurat, pengisian SPT dalam bentuk wizard sehingga lebih mudah dilakukan oleh WP, dengan adanya validasi pengisian SPT maka data yang dilaporkan WP lengkap, dengan penggunaan sistem komputer dapat meminimalisir penggunaan kertas maka lebih ramah lingkungan, dan WP tidak perlu mengirim dokumen pelengkap kecuali diminta oleh KPP melalui account representative.

\section{Pengembangan Hipotesis}

DJP selalu mengupayakan pelayanan pajak semaksimalnya agar WP selalu taat dalam membayar pajak. Salah satu cara memaksimalkan pelayanan pajak dengan memodernisasi sistem administrasi perpajakan. Reformasi sistem e-filing diterapkan oleh DJP sebagai upaya dalam mengoptimalkan pelayanan sehingga diharapkan dapat meningkatkan kepatuhan WP dalam memenuhi kewajiban perpajakan. Persepsi WP yang menganggap $e$-filing bermanfaat dan memudahkan WP dalam melaksanakan kewajiban perpajakannya akan membuat WP puas dalam penggunaan $e$ filing dan juga membuat WP semakin patuh (Husnurrosyidah \& Suhadi, 2017).

Dewi \& Merkusiwati (2018) dan Husnurrosyidah \& Suhadi (2017) menya- 
takan bahwa penerapan e-filing berpengaruh positif terhadap peningkatan kepatuhan pelaporan WPOP. Hal ini disebabkan karena adanya modernisasi sistem administrasi perpajakan, semakin tinggi kemudahan penggunaan sistem e-filing bagi WPOP semakin meningkat pula kepatuhan pelaporan WPOP. Adapun penelitian Lado \& Budiantara (2018) menemukan bahwa E-filing berpengaruh positif terhadap kepatuhan WP. Dari penjelasan tersebut dapat dirumuskan hipotesis sebagai berikut:

$\mathrm{H}_{1} \quad$ : Penerapan e-filing berpengaruh terhadap kepatuhan pelaporan wajib pajak.

Kegiatan sosialisasi harus dilakukan secara efektif dan dilakukan dengan media-media lain yang lebih diketahui masyarakat (Herryanto \& Toly, 2013). Masyarakat yang kini gemar dalam menggunakan media sosial dimanfaatkan oleh DJP untuk mengejar penerimaan negara atau yang disebut pajak. Pemberitaan media juga bisa menjadi sumber data untuk edukasi dan penambahan ilmu bagi WP mengenai perpajakan guna mengejar penerimaan pajak.

Mahadianto \& Astuti (2017) dan Tambun \& Kopong (2017) menemukan bahwa sosialisasi menggunakan media sosial tidak berpengaruh secara signifikan terhadap kepatuhan WP dikarenakan WP tidak tahu adanya sosialisasi yang berisi informasi perpajakan. Dari uraian tersebut dapat ditetapkan hipotesis sebagai berikut:

$\mathrm{H}_{2}$ : Pemanfaatan media sosial memoderasi pengaruh penerapan $e$ filing terhadap kepatuhan pelaporan wajib pajak.

\section{METODE PENELITIAN}

\section{Jenis Penelitian, Metode, dan Populasi}

Jenis metode penelitian ini menggunakan metode kuantitatif, yaitu penelitian yang menekankan analisis data yang diolah dengan metode statistik dalam rangka menguji hipotesis. Data yang digunakan dalam penelitian ini merupakan data primer berupa kuesioner yang diambil secara langsung melalui pengisian kuesioner yang disebarkan melalui media online menggunakan google form.

Populasi pada penelitian ini merupakan wajib pajak orang pribadi, dengan sampel yang digunakan merupakan WP yang menggunakan E-Filing sebagai media pelaporan SPT. Metode pengambilan sampel dalam penelitian ini menggunakan metode purposive sampling dengan kriteria WP yang menggunakan media sosial.

\section{Definisi Operasional dan Indikator Variabel}

Variabel yang akan diukur pada 
penelitian ini terdiri dari penerapan $e$-filing (variabel independen), kepatuhan WP (variabel dependen) dan pemanfaatan media sosial (variabel moderasi). Skala pengukuran yang digunakan adalah skala ordinal. Responden akan menjawab setiap pertanyaan dengan pilihan jawaban yang tersedia. 5 (lima) pilihan jawaban menggunakan skala likert, yaitu sangat tidak setuju, tidak setuju, netral, setuju, dan sangat setuju.

Tabel 1. Definisi Operasional dan Indikator Variabel

\begin{tabular}{|c|c|c|}
\hline Variabel & Definisi Operasional & Indikator \\
\hline $\begin{array}{l}\text { Pemanfaatan } \\
\text { Media Sosial }\end{array}$ & $\begin{array}{l}\text { Aplikasi online yang } \\
\text { digunakan oleh DJP untuk } \\
\text { memberikan informasi } \\
\text { mengenai perpajakan } \\
\text { guna meningkatkan } \\
\text { pengetahuan dan } \\
\text { kepatuhan WP. }\end{array}$ & $\begin{array}{l}\text { Menurut Assegaff (2017), } \\
\text { yaitu: } \\
\text { 1. System use (Penggunaan } \\
\text { sistem); } \\
\text { 2. Individual impact } \\
\text { (Dampak individu); } \\
\text { 3. Knowledge/ information } \\
\text { quality } \\
\text { (Pengetahuan/kualitas } \\
\text { informasi); } \\
\text { 4. User preferences (Harapan } \\
\text { pengguna). }\end{array}$ \\
\hline $\begin{array}{l}\text { Kepatuhan } \\
\text { Pelaporan Wajib } \\
\text { Pajak }\end{array}$ & $\begin{array}{l}\text { Kondisi dimana WP } \\
\text { mengikuti semua } \\
\text { kewajiban perpajakan dan } \\
\text { melakukan hak } \\
\text { perpajakannya (Hutasoit, } \\
\text { 2017). }\end{array}$ & $\begin{array}{l}\text { Menurut Nopiana \& Natalia } \\
\text { (2018), indikator kepatuhan } \\
\text { yaitu: } \\
\text { 1. WP dalam mendaftarkan } \\
\text { diri; } \\
\text { 2. Melaporkan kembali surat } \\
\text { pemberitahuan (SPT); } \\
\text { 3. Perhitungan dan } \\
\text { pembayaran pajak } \\
\text { terutang; }\end{array}$ \\
\hline Penerapan E-filing & $\begin{array}{l}\text { Media online yang dibuat } \\
\text { oleh DJP untuk } \\
\text { mempermudah WP dalam } \\
\text { melaporkan SPT. }\end{array}$ & $\begin{array}{l}\text { Menurut Teo, Lim, \& Lai } \\
\text { (1999), yaitu: } \\
\text { 1. Usage intention (minat } \\
\text { penggunaan); } \\
\text { 2. Attitude (sikap); } \\
\text { 3. Perceived ease of use } \\
\text { (persepsi kemudahan } \\
\text { penggunaan); } \\
\text { 4. Perceived usefulness } \\
\text { (kegunaan persepsi); }\end{array}$ \\
\hline
\end{tabular}




\section{Teknis Analisis}

Teknik analisis data pada penelitian ini yaitu uji validitas dengan melakukan perbandingan antara angka korelasi product moment Pearson ( $\mathrm{r}$ hitung) pada nilai kritis level signifikansi 0,05. Selain itu, uji reliabilitas dengan menggunakan uji Cronbach Alpha. Variabel dianggap reliable jika nilai Cronbach Alpha > 0,7. Uji asumsi klasik yang digunakan yaitu uji normalitas, multikolinearitas dan heteroskedastisitas.

Penelitian ini menggunakan teknik analisis regresi sederhana dengan moderated regression analysis (MRA) untuk menguji pengaruh penerapan e-filing (X) terhadap kepatuhan pelaporan WP (Y) dan pemanfaatan media sosial (Z) sebagai variabel moderasi dengan persamaan sebagai berikut ini :

$$
\begin{aligned}
& Y_{1}=\alpha+\beta_{1} \cdot X+\text { e..... } H_{1} \\
& Y_{2}=\alpha+\beta_{1} \cdot X+\beta_{2} \cdot Z+\beta_{3} \cdot X \cdot Z+\text { e..... } H_{2}
\end{aligned}
$$

Keterangan :

$$
\begin{aligned}
& \mathrm{Y}=\text { Kepatuhan Pelaporan } \\
& \mathrm{X} \quad=\text { Penerapan E-Filing } \\
& \alpha \quad=\text { Konstanta } \\
& \beta_{1}, \beta_{2} \ldots . . . \quad=\text { Koefisien Regresi } \\
& \mathrm{Z} \quad=\text { Pemanfaatan Media sosial } \\
& \text { e } \quad=\text { Variabel diluar kendali }
\end{aligned}
$$

Pengambilan keputusan menggunakan uji $\mathrm{t}$ dengan $\mathrm{t}_{\text {hitung }}>\mathrm{t}_{\text {tabel }}$ maka hipotesis diterima. Tingkat signifikansi $(\alpha)=5 \%$ dan jika sig. penelitian $<0,05$ maka hipotesis diterima.

\section{HASIL DAN PEMBAHASAN}

Deskripsi Responden

Data profil responden dalam penelitian ini dapat digambarkan berdasarkan karakteristik demografis menurut jenis kelamin, usia, pekerjaan, memiliki NPWP, pengguna $e$-filing, dan pengguna media sosial. Berdasarkan data yang diterima dapat disajikan sebagai berikut:

Tabel 2. Jenis Kelamin Responden

\begin{tabular}{lcc}
\hline \multicolumn{1}{c}{$\begin{array}{c}\text { Jenis } \\
\text { Kelamin }\end{array}$} & $\begin{array}{c}\text { Jumlah } \\
\text { Responden }\end{array}$ & Persentase \\
\hline Laki-laki & 53 & $52,5 \%$ \\
Perempuan & 48 & $47,5 \%$ \\
Total & 101 & $100 \%$ \\
\hline
\end{tabular}

Sumber: Data Primer yang diolah, 2020

Hasil diatas menunjukkan bahwa responden laki-laki lebih tinggi dibandingkan responden perempuan dengan selisih $5 \%$. Hal ini menunjukkan bahwa perbedaan pengguna e-filing antara laki-laki dengan perempuan tidak terpaut jauh.

Tabel 3. Usia Responden

\begin{tabular}{lcc}
\hline \multicolumn{1}{c}{ Usia } & $\begin{array}{c}\text { Jumlah } \\
\text { Responden }\end{array}$ & Persentase \\
\hline $\mathbf{2 0 - 3 0}$ tahun & 31 & $30,7 \%$ \\
$\mathbf{3 1 - 4 0}$ tahun & 17 & $16,8 \%$ \\
41-50 tahun & 31 & $30,7 \%$ \\
$\mathbf{5 1 - 6 0}$ tahun & 21 & $20,8 \%$ \\
>60 tahun & 1 & $1 \%$ \\
Total & 101 & $100 \%$ \\
\hline
\end{tabular}

Sumber: Data Primer yang diolah, 2020

Dilihat dari tabel tersebut dapat menunjukkan bahwa responden terbanyak 
adalah sebesar $30,7 \%$ dari seluruh sampel yang diterima, yaitu berusia antara 20 sampai 30 tahun dan 41 sampai 50 tahun. Usia 31 sampai 40 tahun berjumlah 16,8\%, usia 51 sampai 60 tahun berjumlah 20,8\%, dan dalam penelitian terdapat responden berusia lebih dari 60 tahun berjumlah 1\% dari total 101 responden.

Tabel 4. Pekerjaan Responden

\begin{tabular}{lcc}
\hline $\begin{array}{c}\text { Jenis } \\
\text { Pekerjaan }\end{array}$ & $\begin{array}{c}\text { Jumlah } \\
\text { Responden }\end{array}$ & Persentase \\
\hline PNS & 22 & $21,8 \%$ \\
Pengusaha & 8 & $7,9 \%$ \\
Swasta & 70 & $69,3 \%$ \\
TNI/Polri & 1 & $1 \%$ \\
Total & 101 & $100 \%$ \\
\hline
\end{tabular}

Sumber: Data Primer yang diolah, 2020

Data responden yang dapat ditampilkan yaitu jenis pekerjaan responden. Kebanyakan responden yaitu swasta sebesar $69,8 \%$. Swasta adalah mereka yang bekerja di suatu organisasi yang tidak dikuasai oleh pemerintah, dapat berbentuk perusahaan, bank, dan yang lainnya. Selanjutnya yaitu PNS sebesar 21,8\%, pengusaha sebesar $7,9 \%$, dan yang terakhir TNI atau Polri sebesar $1 \%$.

Selain jenis kelamin, usia responden, dan jenis pekerjaan yang memiliki keberagaman, karakteristik lainnya yang terdapat dalam penelitian ini adalah memiliki NPWP, pengguna e-filing, dan pengguna media sosial. Dari 101 responden yang didapat, seluruhnya termasuk keda- lam karateristik tersebut.

\section{Uji Kualitas Data}

\section{Uji Validitas}

Uji Validitas digunakan untuk mengukur kualitas kuesioner yang digunakan sebagai instrumen suatu penelitian atau digunakan untuk mengukur valid atau tidak suatu kuesioner.

Dasar pengambilan keputusan dilakukan dengan membandingkan $\mathrm{r}$ hitung dengan $r$ tabel, untuk df $=n-2$. Dalam hal ini $\mathrm{n}$ adalah jumlah sampel, jumlah sampel dalam penelitian ini adalah 101. Sehingga dapat dihitung $\mathrm{df}=\mathrm{n}-2=101-2=99$, untuk $\alpha=0,05$. Sehingga dapat diketahui $r$ tabel sebesar 0,195. Uji validitas ini dilihat pada nilai corrected item total correlation pada hasil SPSS. Hasil uji validitas dalam penelitian ini dapat disajikan sebagai berikut:

Tabel 5. Hasil Uji Validitas

\begin{tabular}{llccc}
\hline \multicolumn{1}{c}{ Variabel } & $\begin{array}{c}\text { Pertan } \\
\text { yaan }\end{array}$ & $\mathbf{r}_{\text {hitung }}$ & $\mathbf{r}_{\text {tabel }}$ & Ket \\
\hline Penerapan & X1 & 0,756 & 0,195 & Valid \\
E-filing & X2 & 0,809 & 0,195 & Valid \\
& X3 & 0,741 & 0,195 & Valid \\
& X4 & 0.788 & 0,195 & Valid \\
& X5 & 0,823 & 0,195 & Valid \\
& X6 & 0,798 & 0,195 & Valid \\
& X7 & 0,767 & 0,195 & Valid \\
& X8 & 0,851 & 0,195 & Valid \\
& X9 & 0,777 & 0,195 & Valid \\
& X10 & 0,851 & 0,195 & Valid \\
& X11 & 0,763 & 0,195 & Valid \\
& X12 & 0,721 & 0,195 & Valid \\
& X13 & 0,797 & 0,195 & Valid \\
& X14 & 0,804 & 0,195 & Valid \\
\hline & & & & 129
\end{tabular}




\begin{tabular}{lllll}
\hline & X15 & 0,812 & 0,195 & Valid \\
& X16 & 0,848 & 0,195 & Valid \\
& X17 & 0,859 & 0,195 & Valid \\
& X18 & 0,686 & 0,195 & Valid \\
& X19 & 0,703 & 0,195 & Valid \\
& X20 & 0,710 & 0,195 & Valid \\
Kepatuhan & Y1 & 0,638 & 0,195 & Valid \\
Pelaporan & Y2 & 0,782 & 0,195 & Valid \\
Wajib Pajak & Y3 & 0,842 & 0,195 & Valid \\
& Y4 & 0,787 & 0,195 & Valid \\
Pemanfaatan & Y5 & 0,818 & 0,195 & Valid \\
Media & Z2 & 0,588 & 0,195 & Valid \\
Sosial & Z3 & 0,722 & 0,195 & Valid \\
& Z4 & 0,717 & 0,195 & Valid \\
& Z5 & 0,768 & 0,195 & Valid \\
& Z6 & 0,697 & 0,195 & Valid \\
& Z7 & 0,579 & 0,195 & Valid \\
& Z8 & 0,726 & 0,195 & Valid \\
\hline
\end{tabular}

Sumber : Data Primer yang diolah, 2020

Berdasarkan hasil pengujian tersebut dapat diketahui bahwa masing-masing item yang digunakan untuk menyusun masing-masing kuesioner memiliki $\mathrm{r}_{\text {hitung }}>$ $\mathrm{r}_{\text {tabel}}$. Hal ini mengindikasikan bahwa masing-masing item indikator adalah valid sehingga dapat digunakan untuk analisis selanjutnya.

\section{Uji Reliabilitas}

Uji reliabilitas dilakukan untuk memperoleh informasi yang digunakan dapat dipercaya sebagai alat pengumpulan data dan mampu mengungkap informasi yang sebenarnya. uji reliabilitas dalam penelitian ini dengan menggunakan uji Cronbach Alpha. Variabel dianggap reliabel jika nilai signifikansi lebih besar dari 0,7. Hasil uji reliabilitas ditunjukkan pada tabel 3 sebagai berikut :
Tabel 6. Hasil Uji Reliabilitas

\begin{tabular}{llll}
\hline Variabel & $\begin{array}{c}\text { Cronbac } \\
\boldsymbol{h} \text { 's } \\
\text { Alpha }\end{array}$ & $\begin{array}{c}\text { Nilai } \\
\text { Stand } \\
\text { ar }\end{array}$ & $\begin{array}{c}\text { Keterang } \\
\text { an }\end{array}$ \\
\hline $\begin{array}{l}\text { Penerapa } \\
\text { n E-filing }\end{array}$ & 0,847 & 0,7 & Reliabel \\
$\begin{array}{l}\text { Kepatuha } \\
\text { n }\end{array}$ & 0,790 & 0,7 & Reliabel \\
$\begin{array}{l}\text { Pelaporan } \\
\text { Wajib }\end{array}$ & & & \\
$\begin{array}{l}\text { Pajak } \\
\text { Pemanfaa }\end{array}$ & 0,963 & 0,7 & Reliabel \\
tan Media \\
Sosial
\end{tabular}

diketahui bahwa masing-masing variabel memiliki nilai cronbach's alpha lebih besar dari 0,7. Dengan demikian, seluruh variabel reliabel karena cronbach's alpha masing-masing variabel lebih dari dari 0,7 .

\section{Uji Asumsi Klasik}

\section{Uji Normalitas}

Uji normalitas bertujuan untuk menguji apakah variabel bebas, variabel terikat, variabel moderasi atau ketiganya berdistribusi normal atau tidak. Dalam penelitian ini uji normalitas diperoleh dengan menggunakan uji One's Sample Kolmogorov-Smirnov Test, dengan ketentuan nilai sig $\mathrm{K}-\mathrm{S}>0,05$ maka data berdistribusi normal.

Hasil uji normalitas dalam penelitian ini dapat disajikan sebagai berikut: 
Tabel 7. Hasil Uji Normalitas

\begin{tabular}{llll}
\hline \multicolumn{1}{c}{ Variabel } & N & Sig & $\begin{array}{c}\text { Keteranga } \\
\mathbf{n}\end{array}$ \\
\hline Unstandardize & 10 & 0,63 & Normal \\
d Residual & 1 & 1 & \\
\hline Suber & &
\end{tabular}

Sumber : Data Primer yang diolah, 2020

Berdasarkan tabel diatas dapat diketahui bahwa nilai probabilitas signifikansi sebesar 0,631 yang berarti nilai tersebut lebih dari 0,05 . Sehingga data berdistribusi normal. Dengan demikian model regresi layak digunakan untuk penelitian.

\section{Uji Multikolinearitas}

Uji multikolinearitas bertujuan untuk mengetahui apakah model regresi ditemukan adanya korelasi antar variabel bebas. Ada atau tidaknya korelasi dalam model regresi dilihat dari nilai VIF dan Tolerance. Jika nilai VIF $<10$ dan nilai Tolerance $>0,01$ maka tidak terjadi multikolinearitas. Berikut hasil uji multikolinearitas :

Tabel 8. Hasil Uji Multikolinearitas

\begin{tabular}{llll}
\hline Variabel & $\begin{array}{c}\text { Tolera } \\
\text { nce }\end{array}$ & VIF & Keterangan \\
\hline $\begin{array}{l}\text { Penerapa } \\
\text { n E-filing }\end{array}$ & 0,872 & 1,14 & tidak terjadi \\
& & 7 & $\begin{array}{l}\text { multikolinea } \\
\text { ritas }\end{array}$ \\
Pemanfaa & 0,872 & 1,14 & $\begin{array}{l}\text { tidak terjadi } \\
\text { multikolinea } \\
\text { tan Media }\end{array}$ \\
Sosial & & 7 & \begin{tabular}{l} 
ritas \\
\hline
\end{tabular} \\
\hline
\end{tabular}

Sumber : Data Primer yang diolah, 2020

Berdasarkan tabel diatas dapat diketahui bahwa masing-masing variabel memiliki nilai tolerance $>0,10$ dan nilai VIF $<10$ sehingga dapat disimpulkan bahwa seluruh variabel bebas dalam penelitian ini tidak terjadi multikolinearitas.

\section{Uji Heteroskedastisitas}

Uji ini memiliki tujuan untuk menguji apakah di dalam suatu model regresi terjadi ketidaksamaan variasi dari residual satu pengamatan ke pengamatan lain. Model regresi yang baik yaitu tidak terjadi heteroskedastisitas. Uji yang digunakan yaitu Uji Glejser. Hasil pengujian dalam penelitian ini dapat disajikan sebagai berikut:

Tabel 9. Hasil Uji Heteroskedastisitas

\begin{tabular}{lrlr}
\multicolumn{1}{c}{ Variabel } & Sig & \multicolumn{2}{c}{ Keterangan } \\
\hline $\begin{array}{l}\text { Penerapan } \\
\text { E-filing }\end{array}$ & 0,153 & \multicolumn{2}{l}{ Tidak terjadi } \\
Kepatuhan & 0,244 & \multicolumn{2}{l}{ heteroskedastisitas } \\
$\begin{array}{l}\text { Pelaporan } \\
\text { heteroskedastisitas }\end{array}$ \\
$\begin{array}{l}\text { Wajib Pajak } \\
\text { Pemanfaatan }\end{array}$ & 0,083 & Tidak terjadi \\
Media & & heteroskedastisitas \\
Sosial & & \multicolumn{2}{l}{}
\end{tabular}

Sumber : Data Primer yang diolah, 2020

Berdasarkan tabel diatas menunjukkan bahwa semua variabel bebas mempunyai nilai signifikansi 0,05 . Oleh karena itu, dapat disimpulkan bahwa tidak terjadi heteroskedastisitas

\section{Hasil Uji Hipotesis}

Analisis regresi linear sederhana dilakukan untuk menguji pengaruh satu 
variabel bebas terhadap variabel terikat.

Analisis regresi linear sederhana digunakan untuk menguji hipotesis 1 yaitu pengaruh penerapan e-filing (X) terhadap kepatuhan pelaporan wajib pajak badan (Y). Hasil analisis regresi linear sederhana disajikan pada Tabel 10 berikut:

Tabel 10. Hasil Regresi Linier Sederhana

\begin{tabular}{lllllll}
\hline \multicolumn{1}{c}{ Variabel } & Koefisien & Sig. & $\begin{array}{c}\text { Adjusted R } \\
\text { Square }\end{array}$ & F hitung & F tabel & Sig. F \\
\hline $\begin{array}{l}\text { Konstanta } \\
\text { Penerapan }\end{array}$ & 7,810 & 0,000 & 0,403 & 68,477 & 3,94 & 0,000 \\
E-filing & & 0,000 & & & & \\
\hline
\end{tabular}

Sumber : Data Primer yang diolah, 2020

Nilai adjusted $\mathrm{R}$ square pada tabel tersebut sebesar 0,403 yang berarti bahwa variabel penerapan e-filing (X) memiliki pengaruh positif dan berpengaruh sebesar 40,3 persen terhadap variabel kepatuhan pelaporan wajib pajak (Y), sedangkan sisanya sebesar 59,8 persen dijelaskan oleh faktor-faktor lain yang tidak masuk dalam penelitian.

Berdasarkan tabel 10, diketahui bahwa nilai signifikansi variabel penerapan $e$-filing sebesar 0,000 lebih kecil dari 0,05 sehingga hipotesis pertama $\left(\mathbf{H}_{1}\right)$ diterima. Hal ini berarti bahwa penerapan e-filing berpengaruh signifikan pada kepatuhan pelaporan wajib pajak. Nilai koefisien regresi penerapan e-filing sebesar 0,158 menunjukkan adanya pengaruh positif penerapan e-filing terhadap kepatuhan pelaporan wajib pajak. Semakin baik penerapan sistem $e$-filing bagi wajib pajak maka semakin tinggi kepatuhan pelaporan wajib pajak. Wajib pajak yang merasakan manfaat dan mudahnya penggunaan $e$ filing membuat wajib pajak cenderung ingin melaporkan kewajiban pajaknya.

Hasil ini sesuai dengan penelitian Dewi \& Merkusiwati (2018), Husnurrosyidah \& Suhadi (2017), dan Lado \& Budiantara (2018) yang menyatakan bahwa penerapan e-filing berpengaruh positif dalam meningkatkan kepatuhan pelaporan wajib pajak. Sistem e-filing juga diharapkan dapat memberikan kepuasan kepada wajib pajak yang menggunakannya sebagai media pelaporan pajaknya.

Dalam menguji hipotesis 2 dilakukan dengan uji Moderated Regression Analysis (MRA), didapat hasil sebagai berikut : 
Tabel 11. Hasil Moderated Regression Analysis (MRA)

\begin{tabular}{|c|c|c|c|c|c|c|}
\hline Variabel & Koefisien & Sig. & $\begin{array}{l}\text { Adjusted R } \\
\text { Square }\end{array}$ & F hitung & $F$ tabel & Sig. F \\
\hline Konstanta & 16,255 & 0,139 & 0,408 & 23,991 & 2,70 & 0,000 \\
\hline Penerapan $E$-filing & 0,41 & 0,739 & & & & \\
\hline $\begin{array}{l}\text { Pemanfaatan Media } \\
\text { Sosial }\end{array}$ & $-0,268$ & 0,483 & & & & \\
\hline $\begin{array}{l}\text { Penerapan } E \text { - } \\
\text { filing*Pemanfaatan } \\
\text { Media Sosial }\end{array}$ & 0,004 & 0,383 & & & & \\
\hline
\end{tabular}

Nilai adjusted $R$ square yang ditunjukkan pada tabel diatas sebesar 0,408 yang memiliki arti variabel penerapan e-filing, pemanfaatan media sosial dan interaksi antara variabel penerapan $e$ filing dan pemanfaatan media sosial mampu menjelaskan 40,8 persen variasi yang ada pada variabel Kepatuhan Pelaporan Wajib Pajak. Sisanya 59,2 persen dijelaskan oleh faktor lain yang tidak masuk dalam penelitian.

Berdasarkan Tabel 11. diketahui bahwa signifikansi interaksi antara variabel penerapan e-filing dan pemanfaatan media sosial (X.Z) sebesar 0,383 lebih besar dari 0,05 sehingga hipotesis kedua $\left(\mathbf{H}_{2}\right)$ ditolak, hal ini memiliki arti bahwa pemanfaatan media sosial tidak mampu memoderasi pengaruh penerapan e-filing terhadap kepatuhan pelaporan wajib pajak. Hal ini tidak mendukung hipotesis yang diajukan bahwa pemanfaatan media sosial memperkuat hubungan antara penerapan $e$ - filing terhadap kepatuhan pelaporan wajib pajak. hal tersebut disebabkan meskipun wajib pajak telah menerapkan e-filing namun mereka belum mengandalkan media sosial sebagai sumber informasi mengenai perpajakan dan media sosialisasi berbasis internet. WP menilai sosialisasi melalui media sosial belum efektif dikarenakan belum seluruhnya WP menggunakan dan mengerti mengenai media sosial. Sehingga meskipun pemanfaatan media sosial belum bermanfaat secara signifikan sebagai tempat sosialisasi dan penambahan wawasan tentang perpajakan secara online, wajib pajak akan memperoleh informasi secara langsung melalui Direktorat Jenderal Pajak maupun orang lain yang lebih mengerti tentang perpajakan dibandingkan wajib pajak tersebut

Hasil ini bertolak belakang dengan hasil penelitian Herryanto \& Toly (2013) yang menyatakan bahwa sosialisasi menggunakan media sosial dapat dinilai efektif 
dan mudah diketahui oleh masyarakat.

Sedangkan hasil ini sesuai dengan penelitian yang dilakukan oleh Mahadianto \& Astuti (2017) dan Tambun \& Kopong (2017) yang mengungkapkan bahwa sosialisasi menggunakan media sosial tidak berpengaruh secara signifikan terhadap kepatuhan wajib pajak dikarenakan wajib pajak tidak tahu adanya sosialisasi yang berisi informasi perpajakan. Hasil yang berbeda kemungkinan disebabkan oleh adanya persepsi masing-masing responden yang menjadi sampel penelitian.

\section{KESIMPULAN DAN SARAN}

Berdasarkan hasil yang telah dianalisis, dapat disimpulkan hipotesis pertama bahwa penerapan e-filing berpengaruh positif terhadap kepatuhan pelaporan wajib pajak. Hal ini dapat dilihat dari nilai signifikansi sebesar 0,000 dimana nilai tersebut dibawah 0,005. Jika semakin baik sistem penerapan e-filing, maka semakin meningkat pula kepatuhan pelaporan wajib pajak. Sedangkan hipotesis kedua yaitu pemanfaatan media sosial tidak dapat memoderasi pengaruh penerapan e-filing terhadap kepatuhan pelaporan wajib pajak. Hal ini menjelaskan bahwa ada atau tidaknya media sosial tidak berpengaruh pada penerapan e-filing untuk meningkatkan kepatuhan pelaporan wajib pajak dalam melaporkan kewajiban pajaknya.
Dari hasil penelitian ini, peneliti memberi saran kepada penelitian selanjutnya, yaitu dengan menggunakan metode lain dalam pengumpulan data sehingga hasil yang didapat lebih akurat dan dapat menambahkan wajib pajak badan sebagai responden sehingga hasil yang didapat maksimal dan mewakili wajib pajak secara keseluruhan.

\section{DAFTAR PUSTAKA}

Akib, M., \& Amdayani, L. (2013). Analisis Penerapan Sistem E-Filing dalam Menyampaikan Surat Pemberitahuan (SPT) Wajib Pajak Orang Pribadi (Studi pada KPP Pratama Kendari). Jurnal Akuntansi Dan Keuangan Fakultas Ekonomi Dan Bisnis, UHO, 40-52.

Aminnudin, M., Ali;, \& Subadriyah. (2019). Peningkatan Kepatuhan Wajib Pajak melalui Penerapan Sistem E-Filing yang Dimoderasi oleh Pemahaman Internet. Jurnal Bisnis Dan Manajemen Islam, 7(1), 93-112.

Assegaff, S. (2017). Evaluasi Pemanfaatan Media Sosial sebagai Sarana Knowledge Sharing. Jurnal Manajemen Teknologi, 16(3), 271293. Retrieved from http://journal.sbm.itb.ac.id

Aulia, H., Sumarno, \& Indriasih, D. (2019). Pengaruh Return On Assets, Corporate Governance dan Karakter Eksekutif Terhadap Tax Avoidance (Pada Sektor Pertambangan yang Terdaftar di Bursa Efek Indonesia Tahun 2013-2017). Permana : Jurnal Perpajakan, Manajemen, Dan Akuntansi, 11(1), 52-62. 
https://doi.org/10.24905/permana.v11 i1.23

Devano, S., \& Rahayu, S. K. (2006). Perpajakan: Konsep, Teori, dan Isu (First Edit). Jakarta: Kencana.

Dewi, L. P. S. K., \& Merkusiwati, N. K. L. A. (2018). Pengaruh Kesadaran Wajib Pajak, Sanksi Perpajakan, E-Filing, dan Tax Amnesty Terhadap Kepatuhan Pelaporan Wajib Pajak Fakultas Ekonomi dan Bisnis Universitas Udayana ( Unud ), Bali. Jurnal Akuntansi Universitas Udayana, 22, 1626-1655.

Handayani, K. R., \& Tambun, S. (2016). Pengaruh Penerapan Sistem E-Filing dan Pengetahuan Perpajakan Terhadap Kepatuhan Wajib Pajak dengan Sosialisasi sebagai Variabel Moderating. Jurnal Ekonomi Dan Bisnis, 1(2), 59-73.

Herryanto, M., \& Toly, A. A. (2013). Pengaruh Kesadaran Wajib Pajak, Kegiatan Sosialisasi Perpajakan, dan Pemeriksaan Pajak terhadap Penerimaan Pajak Penghasilan di KPP Pratama Surabaya Sawahan. Tax and Accounting Review, 1(1), 124135.

Husnurrosyidah, \& Suhadi. (2017). Pengaruh E-Filing, E-Billing dan EFaktur Terhadap Kepatuhan Pajak pada BMT Se-Kabupaten Kudus. Jurnal Analisa Akuntansi Dan Perpajakan, 1, 97-106.

Hutasoit, G. (2017). Pengaruh Tax Amnesty Terhadap Kepatuhan Wajib Pajak di Kota Palembang. Jurnal Teknologi Informasi, Bisnis Dan Desain, 38-43.

Kaplan, A. M., \& Haenlein, M. (2014). Social Media: Back to the Roots and Back to the Future. Journal of Systems and Information Technology,
Vol 14(Iss 2 pp), 101-104. https://doi.org/10.1108/13287261211 232126

Lado, Y. O., \& Budiantara, M. (2018). Pengaruh Penerapan E-Filing Terhadap Kepatuhan Wajib Pajak Orang Pribadi Pegawai Negeri Sipil Dengan Pemahaman Internet Sebagai Variabel Pemoderasi. Journal Of Accounting, 4(1), 59-84.

Mahadianto, M. Y., \& Astuti, A. D. (2017). Previllage Tax Payer , Sosialisasi Pajak Dan Kepercayaan Pada Otoritas Pajak Terhadap Kepatuhan. Jurnal Kajian Akuntansi, Vol.1(1), 77-86.

Megarani, N., Warno, W., \& Fauzi, M. (2019). The effect of tax planning, company value, and leverage on income smoothing practices in companies listed on Jakarta Islamic Index. Journal of Islamic Accounting and Finance Research, 1(1), 139. https://doi.org/10.21580/jiafr.2019.1. 1.3733

Nasucha, C. (2004). Reformasi Administrasi Publik: Teori dan Praktik. Jakarta: PT. Gramedia Widiasarana Indonesia.

Nopiana, P. R., \& Natalia, E. Y. (2018). Analisis Sosialisasi Pajak Dan Pemanfaatan Teknologi Informasi Terhadap Kepatuhan Pelaporan SPT Wajib Pajak di Kepulauan Riau. Jurnal Akuntansi, Universitas Putera Batam, 3(2), 277-290.

Nurhayati, E., \& Hidayat, N. (2019). Analisis Perbandingan Prediksi Keberterimaan E-Filing dengan EForm. Jurnal Akuntansi Dan Ekonomi, 4(2), 1-13.

Putri, W. S. R., Nurwati, R. N., \& S, M. B. (2016). Pengaruh Media Sosial Terhadap Perilaku Remaja. Jurnal 
Psikologi Universitas Padjadjaran, 3, 1-154.

Sukmana, Y. (2019, April 2). MoneyKompas. Kompas.Com. Retrieved from https://money.kompas.com/read/2019 /04/02/193100926/baru-61-7-persenwajib-pajak-taat-lapor-spt-

Sulistyorini, M., Nurlaela, S., \& S. Chomsatu, Y. (2017). Pengaruh Penggunaan Sistem Administrasi eRegistration, e- Billing, e-SPT, dan eFiling Terhadap Kepatuhan Wajib Pajak (Studi Pada Wajib Pajak Orang Pribadi di RSUD Dr. Moewardi Surakarta). Jurnal Akuntansi, 371379.

Susmita, P. R., \& Supadmi, N. L. (2016). Pengaruh Kualitas Pelayanan, Sanksi Perpajakan, Biaya Kepatuhan Pajak, dan Penerapan E-Filing pada Kepatuhan Wajib Pajak. Jurnal
Akuntansi, 1239-1269.

Tambun, S., \& Kopong, Y. (2017). The Effect of E-Filing on The of Compliance Individual Taxpayer, Moderated by Taxation Socialization. South East Asia Journal of Contemporary Business, Economics and Law, 13(1), 45-51.

Teo, T. S. H., Lim, V. K. G., \& Lai, R. Y. C. (1999). Intrinsic And Extrinsic Motivation in Internet Usage. Omega, The International of Management Science, 27, 25-37.

Vries, L. De, Gensler, S., \& Lee, P. S. H. (2012). Popularity of Brand Posts on Brand Fan Pages : An Investigation of the Effects of Social Media Marketing. Journal of Interactive Marketing, 26, 83-91. https://doi.org/10.1016/j.intmar.2012. 01.003 